\title{
Reduced Expression of Cytoskeletal and Extracellular Matrix Genes in Human Adult Retinal Pigment Epithelium Cells Exposed to Simulated Microgravity
}

\author{
Thomas J. Corydon ${ }^{a}$ Vivek Mann ${ }^{b}$ Lasse Slumstrup ${ }^{a}$ Sascha Kopp ${ }^{c}$ \\ Jayashree Sahana ${ }^{a}$ Anne Louise Askou ${ }^{a}$ Nils E. Magnusson ${ }^{d}$ David Echegoyen ${ }^{c}$ \\ Toke Bek $^{\mathrm{e}}$ Alamelu Sundaresan ${ }^{f}$ Stefan Riwaldt ${ }^{\mathrm{a}}$ Johann Bauer ${ }^{f}$ \\ Manfred Infanger ${ }^{c}$ Daniela Grimm ${ }^{a, c}$

\begin{abstract}
${ }^{a}$ Department of Biomedicine, Aarhus University, Aarhus, Denmark; ${ }^{b}$ Department of Biology, Texas Southern University, Cleburne, Houston, USA; ${ }^{\circ}$ Clinic for Plastic, Aesthetic and Hand Surgery, Ottovon Guericke-University, Magdeburg, Germany; ${ }^{d}$ Medical Research Laboratory, Department of Clinical Medicine, Aarhus University, Aarhus, Denmark; eDepartment of Ophthalmology, Aarhus University
\end{abstract} \\ Hospital, Aarhus, Denmark; ${ }^{\mathrm{f} M a x-P l a n c k-I n s t i t u t e ~ o f ~ B i o c h e m i s t r y, ~ M a r t i n s r i e d, ~ G e r m a n y ~}$
}

\section{Key Words}

Simulated microgravity • Retinal pigment epithelium cells $\cdot 3 \mathrm{D}$ growth $\cdot$ Spheroids $\cdot$ Gene expression $\bullet$ Random Positioning Machine $\cdot$ Cytoskeleton $\bullet$ Vascular endothelial growth factor

\begin{abstract}
Background/Aims: Microgravity $(\mu g)$ has adverse effects on the eye of humans in space. The risk of visual impairment is therefore one of the leading health concerns for NASA. The impact of $\mu \mathrm{g}$ on human adult retinal epithelium (ARPE-19) cells is unknown. Methods: In this study we investigated the influence of simulated $\mu g(\mathrm{~s}-\mu \mathrm{g} ; 5$ and 10 days (d)), using a Random Positioning Machine (RPM), on ARPE-19 cells. We performed phase-contrast/ fluorescent microscopy, qRT-PCR, Western blotting and pathway analysis. Results: Following RPM-exposure a subset of ARPE-19 cells formed multicellular spheroids (MCS), whereas the majority of the cells remained adherent (AD). After $5 \mathrm{~d}$, alterations of F-actin and fibronectin were observed which reverted after 10d-exposure, suggesting a time-dependent adaptation to $\mathrm{s}-\mu \mathrm{g}$. Gene expression analysis of 12 genes involved in cell structure, shape, adhesion, migration, and angiogenesis suggested significant changes after a 10d-RPM-exposure. 11 genes were down-regulated in AD and MCS 10d-RPM-samples compared to $1 \mathrm{~g}$, whereas FLK1 was up-regulated in 5d-and 10d-RPM-MCS-samples. Similarly, TIMP1 was up-regulated in $5 \mathrm{~d}$-RPM-samples, whereas the remaining genes were down-regulated in $5 \mathrm{~d}$-RPM-samples. Western blotting revealed similar changes in VEGF, $\beta$-actin, laminin and fibronectin of $5 \mathrm{~d}$-RPM-samples compared to $10 \mathrm{~d}$, whereas different alterations of $\beta$-tubulin and vimentin were observed. The pathway analysis showed complementing effects of VEGF and integrin $\beta-1$. Conclusions: These findings clearly show that $s-\mu g$ induces significant alterations in the

Thomas J. Corydon

Department of Biomedicine, Aarhus University, Wilhelm Meyers Allé 4, 8000 Aarhus C, (Denmark)

Tel. +45 87167775, E-Mail corydon@biomed.au.dk
\end{abstract}

KARGER 


\section{Cellular Physiology Cell Physiol Biochem 2016;40:1-17 \\ \begin{tabular}{l|l|l}
\hline DOI: 10.1159/000452520 & (c) 2016 The Author(s). Published by S. Karger AG, Basel
\end{tabular} \\ Published online: November 14, 2016 www.karger.com/cpb}

Corydon et al.: Impact of Simulated Microgravity on Human ARPE-19 Cells

F-actin-cytoskeleton and cytoskeleton-related proteins of ARPE-19, in addition to changes in cell growth behavior and gene expression patterns involved in cell structure, growth, shape, migration, adhesion and angiogenesis.

\section{Introduction}

Disturbance of visual function is considered to be a major complication of spaceflights. An identification of the mechanisms underlying e.g. impairment of visual acuity is therefore an important focus area for the microgravity society as well as Space agencies, including the National Aeronautics and Space Administration (NASA). Studies of astronauts participating in space missions on the International Space Station (ISS) have demonstrated spaceflightinduced ocular changes such as choroidal folds, optic disk edema, globe flattening, and hyperoptic shifts [1]. The adverse outcomes were observed in astronauts after a long-term spaceflight and it has been hypothesized that these visual changes are connected to cephalad fluid shifts, intracranial pressure and optic nerve sheath compartment syndrome, as a consequence of prolonged microgravity exposure [1-3].

Simulated microgravity $(\mu g)$ on Earth can be obtained by a number of different techniques including the RPM [4-6], the Horizontally Rotating Bioreactor (HRB) [7-9] and the rotating wall vessel (RWV) [4]. By using a HRB device, Dutt et al. have studied the impact of altered microgravity in the human retinal (HRet) cell line 301-SV-40T $[10,11]$. Following incubation in the HRB vascular endothelial growth factor (VEGF) and basic fibroblast growth factor was found to be up-regulated. Moreover, it was shown that HRB promotes three-dimensional (3D) assembly when HRet was co-cultured with bovine endothelial cells (ECs) [11]. Also Tombran-Tink and Barnstable found evidence showing that a space shuttle flight microgravity environment disturbs normal retinal development including loss of retinal pigment epithelium (RPE) cells in a rodent model [12]. Furthermore, Roberts and coworkers demonstrated that simulated microgravity using a RWV bioreactor might induce an inflammatory response in human RPE (hRPE [13]) cells [14]. RPE cells constitute the pigmented layer of retina outside the neurosensory retina that nourishes retinal visual cells. Hence, the RPE cells are involved in several important processes including autophagy [15, 16] and protection against oxidative damage [17].

In order to investigate the effect of annulling gravity in RPE cells we exposed human adult retinal epithelium cells (ARPE-19) to simulated microgravity using a RPM. The cells were cultured on the RPM for $5 \mathrm{~d}$ and $10 \mathrm{~d}$, respectively. ARPE- 19 cells that remained adherent to the bottom of the culture flask (AD) and cells forming multicellular 3D aggregates (MCS) were isolated individually. The cytoskeleton and gene expression in AD and MCS cells were scrutinized and compared to ARPE-19 cells, cultivated under normal gravity $(1 g)$. Our study revealed microgravity-provoked cytoskeletal alterations of ARPE-19, in addition to changes in cell growth and expression pattern of selected genes involved in cell structure, shape, adhesion, extracellular matrix, migration, and angiogenesis.

\section{Materials and Methods}

\section{Cell culture}

ARPE-19 human adult retinal pigment epithelium cells (catalog number CRL-2302; American Type Culture Collection, Boras, Sweden) were cultured in Dulbecco's Modified Eagle Medium (DMEM) (Lonza, Verviers, Belgium), supplemented with 10\% fetal bovine serum (Biochrom AG, Berlin, Germany), 100 IU penicillin/mL and $100 \mu \mathrm{g}$ streptomycin/mL (Life Technologies, Naerum, Denmark) in $75 \mathrm{~cm}^{2}$ ventilated cell culture flasks (Sarstedt AG, Nümbrecht, Germany) under standard conditions of $37^{\circ} \mathrm{C}$ and $5 \% \mathrm{CO}_{2}$ as previously described [18-20]. ARPE-19 cells form stable monolayers.

For RPM experiments, ARPE-19 cells were seeded into $25 \mathrm{~cm}^{2}$ ventilated cell culture flasks (Sarstedt $\mathrm{AG}$ ), and given at least $24 \mathrm{~h}$ to properly attach to the bottom of the flasks, before the flasks were filled with 


\section{Cellular Physiology Cell Physiol Biochem 2016;40:1-17 \begin{tabular}{l|l|l}
\hline DOI: 10.1159/000452520 & ○ 2016 The Author(s). Published by S. Karger AG, Basel \\
\hline
\end{tabular} and Biochemistry Published online: November 14, 2016 www.karger.com/cpb \\ Corydon et al.: Impact of Simulated Microgravity on Human ARPE-19 Cells}

complete medium and fixed on the RPM or used as controls [21]. For 10d-experiments, it was necessary to exchange $50 \%$ of the medium with fresh medium after $5 \mathrm{~d}$, to ensure proper concentrations of nutrients and waste products. To assure that any MCS were not removed in the process, the flasks were placed upright, to allow the MCS to sediment before carefully aspirating the old medium and refilling with fresh medium.

\section{Random Positioning Machine}

Microgravity conditions were simulated using a desktop RPM (Airbus Defense and Space, former Dutch Space, Leiden, Netherlands). The RPM rotates a central frame around two perpendicular axes, randomly changing the direction of rotation and the angular velocity anywhere between $60^{\circ} / \mathrm{s}$ and $75^{\circ} / \mathrm{s}$ around both axes. Thus, the direction of the gravitational acceleration affecting the samples is continuously randomized, and the magnitude of the net gravitational vector will over time approach zero, producing a simulated state of microgravity. The RPM was placed inside a commercial incubator under standard conditions at $37^{\circ} \mathrm{C}$ and $5 \% \mathrm{CO}_{2}$ with up to fifteen $25 \mathrm{~cm}^{2}$ flasks fixed to the central frame. The $25 \mathrm{~cm}^{2}$ flasks were all completely filled with medium without air bubbles, to prevent sloshing of the medium and shear stress on the cells. Samples were run on the RPM for $5 \mathrm{~d}$ and $10 \mathrm{~d}$, while an equivalent number of $25 \mathrm{~cm}^{2}$ flasks, also filled with medium, were placed in the same incubator, to serve as $1 g$-controls to the RPM samples.

\section{Immunofluorescence of fibronectin and F-actin-staining}

Fibronectin and F-actin were visualized by seeding $5 \times 10^{5}$ cells into a SlideFlask chamber (Nunc, Roskilde, Denmark). The cells were then given $24 \mathrm{~h}$ to adhere to the surface of the chamber before being filled with medium and run on the RPM for $5 \mathrm{~d}$ or $10 \mathrm{~d}$, or acting as $1 g$-controls in the same incubator. After $5 \mathrm{~d}$ in the $10 \mathrm{~d}$-experiment $50 \%$ of the medium in the chamber was carefully aspirated and exchanged with fresh medium. After $5 \mathrm{~d}$ or $10 \mathrm{~d}$ of cultivation the chambers were washed twice with DPBS (Life Technologies) and fixed with $4 \%$ paraformaldehyde for 30 minutes. After fixation, the cells were permeabilized with Triton-X-100 (Sigma, Taufkirchen, Germany) and subsequently washed twice with DPBS. Fibronectin was visualized by immunofluorescence using a primary antibody against fibronectin (1:200, F3648, Sigma). After incubation with the primary antibody, the cells were washed twice with DPBS and afterwards incubated with a secondary antibody conjugated to Alexa Fluor 488 antibody (1:400, 4412S and 4408S, both Cell Signaling Technology, Danvers, MA, USA). F-actin was visualized by incubating with phalloidin conjugated to TRITC for 30 minutes (Merck Life Sciences, Hellerup, Denmark) before washing away unbound phalloidin. For both fibronectin and F-actin staining, Fluoroshield with 4', 6-diamidino-2-phenylindole (DAPI) (Sigma) was used for nuclear counterstaining and mounting before subsequent imaging by confocal laser scanning microscopy (CLSM) (see below).

\section{Microscopy}

Phase contrast microscopy was performed before and after any RPM experiment, to ensure viability and to determine morphological changes of the cell cultures. Pictures were taken using a Canon EOS 550D camera (Canon GmbH, Krefeld, Germany) through a Leica DM IL LED inverted microscope (Leica Microsystems, Wetzlar, Germany).

Fluorescent staining was analyzed using a Zeiss LSM 710 CLSM (Zeiss, Jena, Germany) fitted with a Plan-Apochromat $63 \times 1.4$ objective as previously described $[18,22]$. Excitation and emission wavelengths for Alexa Fluor 488 were $\lambda_{\mathrm{ex}}=488 \mathrm{~nm}$ and $\lambda_{\mathrm{em}} 525 \mathrm{~nm}$. Correspondingly for TRITC: $\lambda_{\mathrm{ex}}=532 \mathrm{~nm}$ and $\lambda_{\mathrm{em}}=$ $576 \mathrm{~nm}$.

\section{RNA isolation}

Cells from RPM experiments were detached from the culture flasks with scrapers and transferred to tubes for isolation by centrifugation at $3400 \mathrm{~g}$ for 10 minutes at $4^{\circ} \mathrm{C}$. Any MCS were isolated by centrifuging the culture medium, in which the MCS were suspended. Total RNA was extracted from the samples with an AllPrep RNA/Protein Kit (Qiagen, Hilden, Germany) according to the manufacturer's instructions. RNA concentrations and quality were determined spectrophotometrically at $260 \mathrm{~nm}$ with a SpectraMax M2 Microplate Reader (Molecular Devices, Sunnyvale, CA, USA). The isolated RNA had an A260/A280 ratio of >1.5. cDNA for quantitative PCR was obtained using a First-Strand cDNA Synthesis Kit (Thermo Scientific) according to the manufacturer's instructions. 


\section{Cellular Physiology Cell Physiol Biochem 2016;40:1-17 \begin{tabular}{ll|l} 
and Biochemistry & Dublished online: November 14, 2016 & $\begin{array}{l}\text { @ 2016 The Author(s). Published by S. Karger AG, Basel } \\
\text { www.karger.com/cpb }\end{array}$ \\
\hline
\end{tabular} \\ Corydon et al.: Impact of Simulated Microgravity on Human ARPE-19 Cells}

Quantitative real-time PCR

Quantitative real-time PCR

(qRT-PCR) was used to determine the expression levels of the genes of interest $[23,24]$. Appropriate primers were designed using Primer express software (Applied Biosystems, Darmstadt, Germany) with a $\mathrm{Tm}$ of $60^{\circ} \mathrm{C}$ (Table 1). All primers were synthesized by TIB Molbiol (Berlin, Germany). cDNA analysis was performed using a 7500 Fast Real-Time PCR System with Fast SYBR Master Mix (both Applied Biosystems). Final reaction volume was $25 \mu \mathrm{l}$, including $1 \mu \mathrm{l}$ template cDNA and a primer concentration of 500 nM. PCR conditions were as follows: $20 \mathrm{~s}$ at $95^{\circ} \mathrm{C}, 40$ cycles of $3 \mathrm{~s}$ at $95^{\circ} \mathrm{C}, 1$ min at $60^{\circ} \mathrm{C}$, followed by a melting curve analysis, with a temperature gradient from $60^{\circ} \mathrm{C}$ to $95^{\circ} \mathrm{C}$ in $0.3^{\circ} \mathrm{C}$ increments. If all amplicons showed $a \mathrm{~T}_{\mathrm{m}}$ similar to the one predicted by the Primer Express software, the PCR reaction was considered specific. Each sample was measured in triplicate. Relative transcription levels were quantified using the comparative $\mathrm{C}_{\mathrm{T}}\left(\Delta \Delta \mathrm{C}_{\mathrm{T}}\right)$ method. The transcription level of the housekeeping gene $18 S$ rRNA was used as a reference gene for data normalization.
Table 1. Primers used for qRT-PCR

\begin{tabular}{|c|c|c|}
\hline Gene & Primer name & Sequence $\left(5^{\prime}-3^{\prime}\right.$ direction $)$ \\
\hline \multirow[t]{2}{*}{$18 S$ rRNA } & $18 S-F$ & GGAGCCTGCGGCTTAATTT \\
\hline & $18 \mathrm{~S}-\mathrm{R}$ & CAACTAAGAACGGCCATGCA \\
\hline \multirow[t]{2}{*}{ ACTB } & ACTB-F & TGCCGACAGGATGCAGAAG \\
\hline & ACTB-R & GCCGATCCACACGGAGTACT \\
\hline \multirow[t]{2}{*}{ TUBB } & TUBB-F & CTGGACCGCATCTCTGTGTACTAC \\
\hline & TUBB-R & GACCTGAGCGAACAGAGTCCAT \\
\hline \multirow[t]{2}{*}{ LAMB2 } & LAMB2-F & TGCTCATGGTCAATGCTAATCTG \\
\hline & LAMB2-R & TCTATCAATCCTCTTCCTTGGACAA \\
\hline \multirow[t]{2}{*}{ FN1 } & FN1-F & AGATCTACCTGTACACCTTGAATGACA \\
\hline & FN1-R & CATGATACCAGCAAGGAATTGG \\
\hline \multirow[t]{2}{*}{ VEGFA } & VEGFA-F & GCGCTGATAGACATCCATGAAC \\
\hline & VEGFA-R & CTACCTCCACCATGCCAAGTG \\
\hline \multirow[t]{2}{*}{$\operatorname{COL4}$} & COL4A5-F & GGTACCTGTAACTACTATGCCAACTCCTA \\
\hline & COL4A5-R & CGGCTAATTCGTGTCCTCAAG \\
\hline \multirow[t]{2}{*}{ FLK1 } & FLK1-F & TCTTCTGGCTACTTCTTGTCATCATC \\
\hline & FLK1-R & GATGGACAAGTAGCCTGTCTTCAGT \\
\hline \multirow[t]{2}{*}{ ITGB1 } & ITGB1-F & GAAAACAGCGCATATCTGGAAATT \\
\hline & ITGB1-R & CAGCCAATCAGTGATCCACAA \\
\hline \multirow[t]{2}{*}{ ITGB3 } & ITGB3-F & CGACCGAAAAGAATTCGCTAA \\
\hline & ITGB3-R & CGGTACGTGATATTGGTGAAGGTA \\
\hline \multirow[t]{2}{*}{ KRT8 } & KRT8-F & GATCTCTGAGATGAACCGGAACA \\
\hline & KRT8-R & GCTCGGCATCTGCAATGG \\
\hline \multirow[t]{2}{*}{ VIM } & VIM-F & TTCAGAGAGAGGAAGCCGAAAAC \\
\hline & VIM-R & AGATTCCACTTTGCGTTCAAGGT \\
\hline \multirow[t]{2}{*}{ TIMP1 } & TIMP1-F & GCCATCGCCGCAGATC \\
\hline & TIMP1-R & GCTATCAGCCACAGCAACAACA \\
\hline
\end{tabular}

Western blot analysis

SDS-PAGE, immunoblotting and densitometry were carried out as previously described $[25,26]$. Antibodies against the following antigens were used: Fibronectin (F3648), laminin (L9393), $\beta$-tubulin (T5293), vimentin (V5255) (all from Sigma, Taufkirchen, Germany), VEGF (ab46154, Abcam, Cambridge, UK), and GAPDH (5174s, Cell Signaling Technology, Danvers, MA, USA) all used at dilution of 1:1000, and $\beta$-actin (A5316, Sigma) was used at a dilution of 1:4000. Secondary HRP-conjugated antibodies were used at a dilution of 1:4000 (anti-mouse, P0260, Dako, Glostrup, Denmark) and 1:2000 (anti-rabbit, P0399, Dako). Bound antibodies were visualized with Clarity Western ECL substrate (Bio-Rad, Hercules, CA, USA) on an ImageQuant LAS 4000 digital imaging system (GE Healthcare, Brøndby, Denmark) as previously described [18]. Densitometric quantification of the bands was carried out using ImageJ (http://rsb.info.nih.gov/ij/).

Pathway analysis

To investigate and visualize interactions between proteins and genes selected, we entered relevant UniProtKB entry numbers in the Pathway Studio v.11 software (Elsevier Research Solutions, Amsterdam, the Netherlands). The genes identified were analysed according to their mutual regulation. The proteins were evaluated in regard to their cellular localization and their interaction.

\section{Assessment of released VEGF protein by ELISA}

Released VEGF levels were measured using in-house time resolved immunofluorometric assays (TRIFMA) according to previously described methods [21, 23, 27]. In brief, the supernatant samples were diluted 1:2 and 96-well plates were read using a VICTOR 2030 instrument (Perkin Elmer, Inc.). Standard curves were used to calculate the concentrations using the standard software implemented in the VICTOR 2030. 


\section{Cellular Physiology Cell Physiol Biochem 2016;40:1-17 \begin{tabular}{ll|l|l} 
and Biochemistry & Published online: November 14, 2016 & $\begin{array}{l}\text { @ 2016 The Author(s). Published by S. Karger AG, Basel } \\
\text { www.karger.com/cpb }\end{array}$ \\
\hline
\end{tabular} Corydon et al.: Impact of Simulated Microgravity on Human ARPE-19 Cells}

Fig. 1. Morphologic examination of the ARPE-19 cells. Phase-contrast microscopy images of ARPE-19 cells after establishment before start of the experiment (T0) (A), after $3 \mathrm{~d}$ at $1 g$ (B), and after they have been cultured on the RPM for $5 d(D)$ and $10 d(F)$. Control samples of $5 \mathrm{~d}(\mathrm{C})$ and $10 \mathrm{~d}(\mathrm{E})$ formed no MCS. The samples cultured for $5 d(D)$ and $10 d(F)$ on the RPM formed two distinct populations represented by cells that remained adherently as a monolayer or MCS. Generally, the MCS build after 10d (green arrowheads in F) increased in size compared to the MCS formed after $5 \mathrm{~d}$ (green arrowheads in D). In both cases less-adherent cells, probably representing cells that have the potential to form MCS are observed (purple arrowheads in D and F). Scale bar: $100 \mu \mathrm{m}$.

\section{Statistical analysis}

All statistical analyses were performed using SPSS 16.0 software (SPSS, Inc., Chicago, IL, USA). Data are presented as the mean \pm SD. Statistical differences between two groups were evaluated using Mann-Whitney-U. $\mathrm{P}<0.05$ was considered statistically significant.
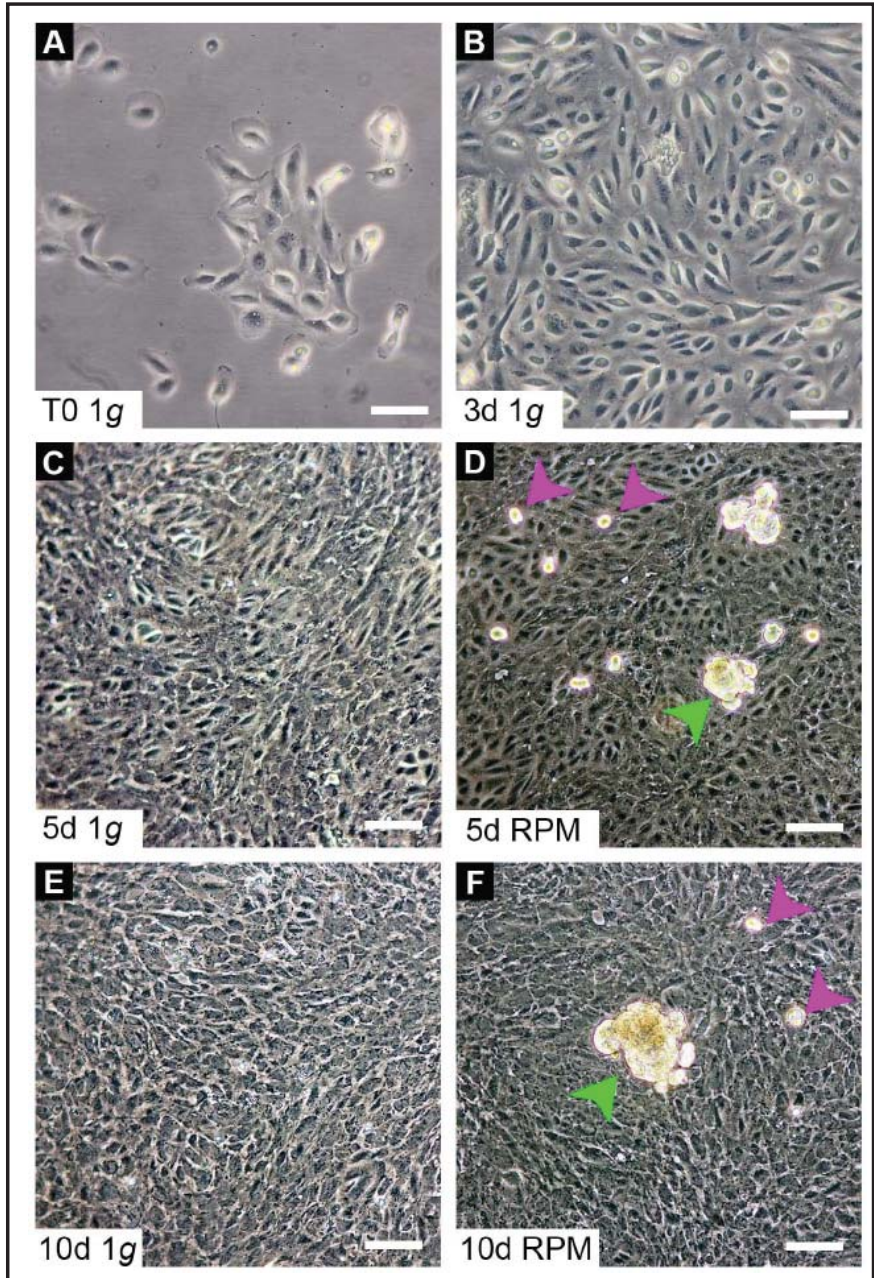

\section{Results}

Growth pattern of ARPE-19 cells reveals several phenotypes during RPM-exposure

We used freshly established ARPE-19 cells and investigated them under conditions of $s-\mu g$ using a RPM, a so-called ESA recommended ground-based facility. The $1 g$-controlsample was placed next to the machine for two selected time points ( 5 and $10 \mathrm{~d}$ ). The cells were subjected randomly to both conditions at time point 0 (T0). As shown in Fig. 1A and $\mathrm{B}$ the ARPE-19 cells were growing in a monolayer at T0 and $3 \mathrm{~d}$ after the experiment was started. Following incubation at the two conditions the cells were then collected for imaging or harvested for further processing including gene expression analysis and protein amount assessments.

We first analyzed the morphology of ARPE-19 cells exposed to microgravity $(\mu g)$ conditions by standard phase-contrast imaging. The experiment revealed ARPE-19 cells growing in adherent (AD) monolayers during exposure to static $1 g$-conditions (Fig. 1C and E). The $1 g$-control cells showed no 3D growth and only the AD phenotype was observed. In contrast the ARPE-19 cells formed small compact round 3D MCS following exposure to simulated $\mu g$ conditions for $5 \mathrm{~d}$ and $10 \mathrm{~d}$ on the RPM. The MCS were floating in the cultivation medium or found to be partly attached to the adherent monolayer. In addition to the MCS partly detached unicellular aggregates (preMCS) were also observed in the $\mu g$-samples, resembling cells in a precursor stage prior to MCS formation. As early as after 5d-exposure 


\section{Cellular Physiology Cell Physiol Biochem 2016;40:1-17

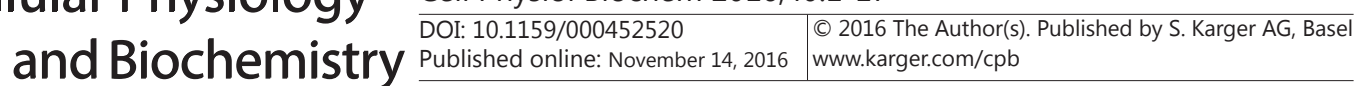

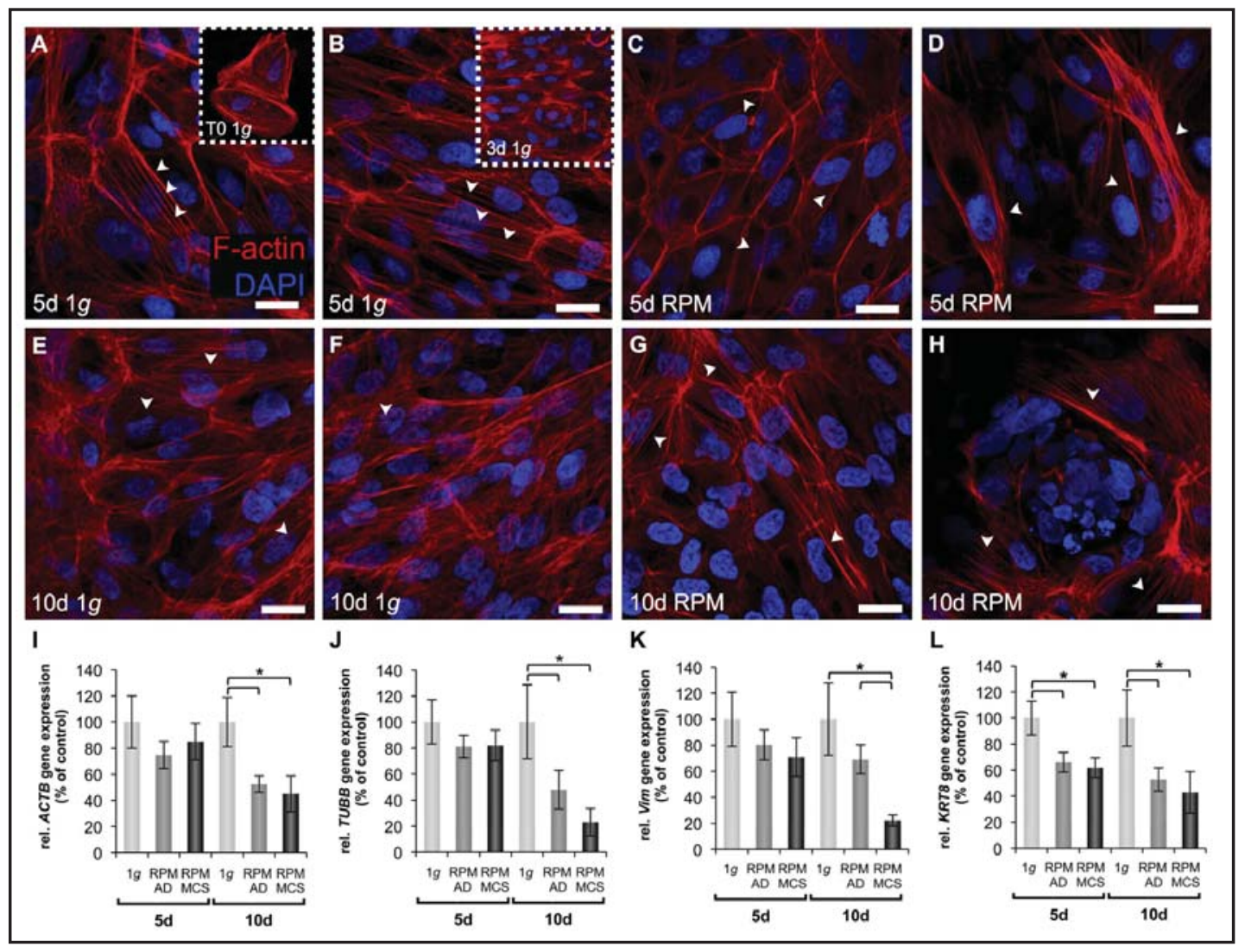

Fig. 2. Cytoskeletal staining of F-actin microfilaments and quantitative alterations of genes of cytoskeletal proteins in ARPE-19 cells exposed to simulated microgravity. (A-H) CLSM after a 5d-exposure (C, D) and a 10d-exposure $(\mathrm{G}, \mathrm{H})$ on the RPM and their corresponding $1 g$-control cells $(\mathrm{A}, \mathrm{B}, \mathrm{E}, \mathrm{F})$. Inserts of $2 \mathrm{~A}$ and B show freshly established ARPE-19 cells with normal cytoskeleton at T0 $(1 g)$ and $3 \mathrm{~d}(1 \mathrm{~g})$, respectively. Red staining: TRITC-phalloidin to visualize the F-actin; blue staining: DAPI labeling of nucleus. White arrowheads indicate region of interest. Scale bar: $20 \mu \mathrm{m}$. (I-L) Gene expression analyses of cytoskeletal genes assessed by qRT-PCR. After $5 \mathrm{~d}$ and $10 \mathrm{~d} 1 \mathrm{~g}$-control, RPM-adherent (AD) cells, and RPM-multicellular spheroids (MCS) were analyzed for their relative expression levels of (I) ACTB; (J) TUBB; (K) VIM; (L) KRT8 correlated to $18 S$ rRNA. The $5 \mathrm{~d}$ and $10 \mathrm{~d} 1 \mathrm{~g}$-controls were set to $100 \% *=\mathrm{p}<0.05$.

preMCS and MCS were observed in the $\mu g$-sample, but not in the $1 g$-control-samples (Fig. 1C and D). The numbers of MCS increased from $5 \mathrm{~d}$ to $10 \mathrm{~d}$, and a concomitant decline in the numbers of preMCS was observed in the $\mu g$-sample (Fig. 1D and F). From the presented data it is also seen that MCS grow in size as increased numbers of cells in the spheroids were observed in 10d-MCS compared to the MCS at $5 \mathrm{~d}$. Thus, the AD and MCS phenotypes were observed at both $5 \mathrm{~d}$ and $10 \mathrm{~d}$.

\section{RPM-induced alterations of the cytoskeleton}

We performed immunostaining and confocal laser scanning microscopy (CLSM) of fixed and F-actin-stained ARPE-19 cells to investigate whether simulated microgravity introduces further changes of the cell shape and in the cytoskeleton after cultivation for $5 \mathrm{~d}$ and $10 \mathrm{~d}$ on the RPM. As expected well-organized intracellular F-actin filaments were observed under static $1 g$-conditions (Fig. 2A, B, E and F). The inserts of Fig. 2A and B show freshly established ARPE-19 cells with normal cytoskeleton at T0 and 3d. Following RPM-exposure for $5 \mathrm{~d}$, the intracellular F-actin filaments had almost disappeared in favor of development of F-actin structures accumulated at the cell boundaries (Fig. 2C and D). Notably, further exposure to $\mu g$-conditions for another $5 \mathrm{~d}$ resulted in a F-actin staining pattern similar to the 


\section{Cellular Physiology Cell Physiol Biochem 2016;40:1-17 \begin{tabular}{l|l|l}
\hline DOI: 10.1159/000452520 & (c) 2016 The Author(s). Published by S. Karger AG, Basel \\
\hline
\end{tabular} and Biochemistry Published online: November 14, 2016 www.karger.com/cpb \\ Corydon et al.: Impact of Simulated Microgravity on Human ARPE-19 Cells}

$1 g$-control (Fig. 2G and H). In addition, F-actin filaments appeared to be located on the cell boundaries of MCS formed after a 10d-exposure. As shown in Fig. 1 relatively few MCS were formed during the RPM-experiment. Consequently, only a modest number of MCS could be analyzed by CLSM. However, the result shown in Fig. $2 \mathrm{H}$ is a representative example of the investigated MCS.

Simulated microgravity changes the gene expression of both cytoskeletal and cytoskeletal binding proteins

Changes in gene expression levels of four cytoskeletal genes - $\beta$-actin (ACTB), $\beta$-tubulin $(T U B B)$, vimentin (VIM) and cytokeratin $8(K R T 8)$ - as a response to altered gravity conditions facilitated by the RPM were investigated by quantitative real-time PCR (qRT-PCR). As shown in Fig. 2I the expression of ACTB was slightly reduced in both AD and MCS after 5d-RPMexposure. This tendency further developed in the samples experiencing simulated $\mu \mathrm{g}$ for $10 \mathrm{~d}$ resulting in a significantly $(\mathrm{p}<0.05)$ reduced expression of ACTB in AD and MCS amounting to $52 \%$ and $45 \%$ compared to $1 g$-control-samples, respectively (Fig. 2 I).

For the other three investigated cytoskeletal genes similar expression patterns were obtained. The expression of TUBB and VIM was only markedly reduced in AD- and MCSsamples following incubation at simulated $\mu g$ conditions for $5 \mathrm{~d}$ (Fig. $2 \mathrm{~J}$ and $\mathrm{K}$ ). After a $10 \mathrm{~d}$-exposure the expression level of TUBB was significantly reduced to $50 \%$ and $29 \%$ compared to $1 g$-samples (Fig. 2J). Similarly, qRT-PCR analysis showed that expression of VIM in AD and MCS was significantly reduced to $69 \%$ and $24 \%$ compared to the $1 g$-samples (Fig. 2K). In the case of KRT8 expression levels following both $5 \mathrm{~d}$ - and $10 \mathrm{~d}$-RPM-exposure to simulated microgravity were significantly decreased amounting to $67 \%$ and $60 \%$ in AD and MCS compared to the corresponding $1 g$-samples at $5 \mathrm{~d}$, and $52 \%$ and $41 \%$ in AD and MCS compared to the corresponding $1 \mathrm{~g}$-samples at $10 \mathrm{~d}$ (Fig. 2L).

Changes in extracellular matrix and related proteins

We next investigated whether reduced gravity influenced the cellular distribution of fibronectin, which mediates a wide variety of cellular interactions with the extracellular matrix (ECM) and plays important roles in cell adhesion, migration and growth, as well as introduce changes in the expression of ECM genes.

Immunostaining and CLSM analysis showed that the majority of the anti-fibronectin positive ECM material was accumulated in the extracellular space around the cells at $1 g$-conditions for $5 \mathrm{~d}$ (Fig. $3 \mathrm{~A}$ and B). The amount of fibronectin was clearly reduced at simulated $\mu g$-conditions (Fig. $3 \mathrm{C}$ and D). Extension of the period of simulated $\mu g$ to $10 \mathrm{~d}$ revealed a reduced amount of fibronectin protein compared with $1 g$ (Fig. 3E-H). These findings indicated an overall reduction of anti-fibronectin positive signals in samples experiencing simulated $\mu g$ compared to the $1 g$-controls (compare Fig. 3A with Fig. $3 \mathrm{C}$, and Fig. 3E with Fig. 3G).

A representative example of anti-fibronectin staining of a MCS is shown in Fig. 3D. The image suggests that fibronectin, similar to F-actin, is localized at the cell boundaries and in the extracellular space around the MCS.

\section{Simulated microgravity alters the gene expression of ECM proteins}

Simulated microgravity conditions also altered the gene expression of fibronectin and other investigated ECM proteins in the ARPE-19 cells (Fig. 3I-N). Hence, at $5 \mathrm{~d}$ the expression of $F N 1$ (fibronectin) was significantly decreased to $51 \%$ and $31 \%$ of the $1 g$-controls as determined by qRT-PCR (Fig. 3I). The expression of FN1 was further reduced at $10 \mathrm{~d}$ amounting to $32 \%$ and $24 \%$ of that observed in the $1 g$-control cells (Fig. 3I). For LAMB2 (laminin subunit $\beta-2$ ) the expression was markedly reduced to $49 \%$ in the AD-sample after $5 \mathrm{~d}$, whereas LAMB2 expression in the $5 \mathrm{~d}$ MCS-sample was only decreased to $83 \%$ of that in the $1 g$-control (Fig. 3J). However, in both the AD- and MCS-samples subjected to simulated microgravity for $10 \mathrm{~d} L A M B 2$ expression was significantly reduced to $38 \%$ and $44 \%$ compared to $1 g$-controls (Fig. 3J). 


\section{Cellular Physiology Cell Physiol Biochem 2016;40:1-17 \begin{tabular}{ll|l} 
DOI: 10.1159/000452520 & O 2016 The Author(s). Published by S. Karger AG, Basel \\
wumb Biochemistry
\end{tabular}}

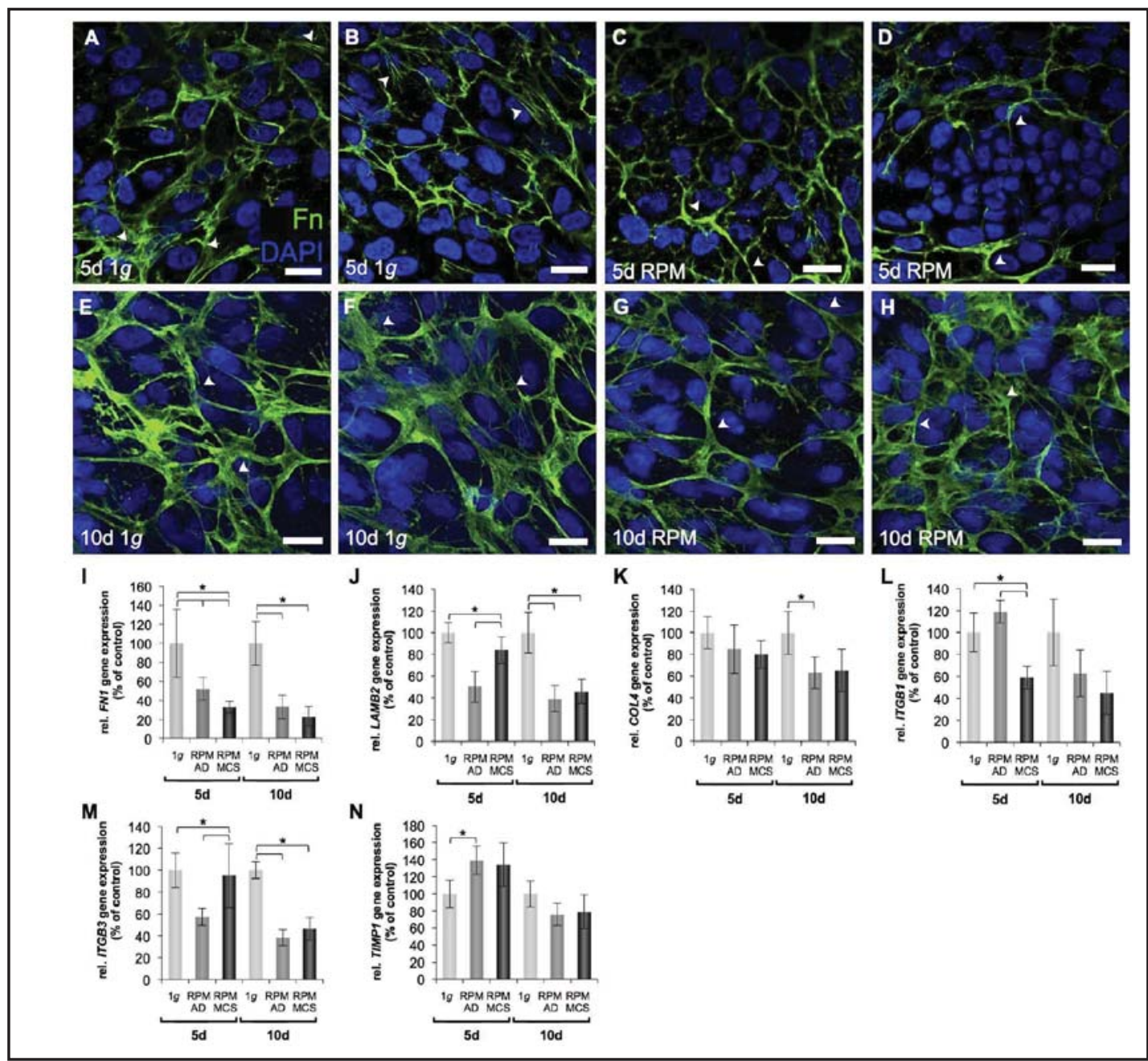

Fig. 3. Cytoskeletal staining of fibronectin and quantitative alterations of extracellular matrix genes in ARPE-19 cells exposed to simulated microgravity. (A-H) CLSM after a 5d-exposure (C, D) and a 10d-exposure $(G, H)$ on the RPM and their corresponding $1 g$-control cells (A, B, E, F). Green staining: Alexa Fluor 488-conjugated antibodies to visualize fibronectin filaments; blue staining: DAPI labeling of nucleus. White arrowheads indicate region of interest. Scale bar: $20 \mu \mathrm{m}$. (I-N) Gene expression analyses of ECM genes assessed by qRT-PCR. After $5 \mathrm{~d}$ and $10 \mathrm{~d} 1 \mathrm{~g}$-control, RPM-adherent (AD) cells and RPM-MCS were analyzed for their relative expression levels of (I) FN1; (J) LAMB2; (K) COL4; (L) ITGB1; (M) ITGB3; (N) TIMP1 correlated to $18 \mathrm{~s} r R N A$. The $5 \mathrm{~d}$ and $10 \mathrm{~d} 1 \mathrm{~g}$-controls were set to $100 \% *=\mathrm{p}<0.05$.

As shown in Fig. $3 \mathrm{~K}$ simulated $\mu g$ only has a minor impact on the expression of COL4 (type IV collagen) at $5 \mathrm{~d}$ in both AD- and MCS-samples. At $10 \mathrm{~d}$ more pronounced declines were observed amounting to $63 \%$ of the $1 g$-control samples (Fig. $3 \mathrm{~K}$ ). For both ITGB1 (integrin- $\beta$ - 1 ) and TIMP1 (tissue inhibitor of metalloproteinase 1) expression levels in the 5d-RPM-ADsamples increased to $120 \%$ and $136 \%$, respectively, compared to the $1 g$-controls (Fig. $3 \mathrm{~L}$ and $\mathrm{N}$ ). In case of, ITGB1 the expression level observed in the MCS-sample was reduced to $57 \%$. Analysis of the $10 \mathrm{~d}$ samples showed non-significant down-regulation of the ITGB1 expression in both AD and MCS (Fig. 3L). In the 5d-MCS-sample the expression of TIMP1 increased to $132 \%$ of the $1 g$-control and was comparable to that observed in the $5 \mathrm{~d}$-RPMAD-sample (Fig. $3 \mathrm{~N}$ ). However, the gene expression levels of TIMP1 were diminished in both 10d-RPM-AD- and 10d-RPM-MCS-samples (Fig. 3N).

Finally, the analysis of ITGB3 (integrin- $\beta$-3) showed that the expression of this gene in the $5 \mathrm{~d}$-RPM-AD-sample was significantly decreased in $5 \mathrm{~d}$-RPM-AD-samples to $57 \%$ of the 


\section{Cellular Physiology \\ Cell Physiol Biochem 2016;40:1-17 \\ \begin{tabular}{l|l|l}
\hline DOI: 10.1159/000452520 & ( ) 2016 The Author(s). Published by S. Karger AG, Basel
\end{tabular}

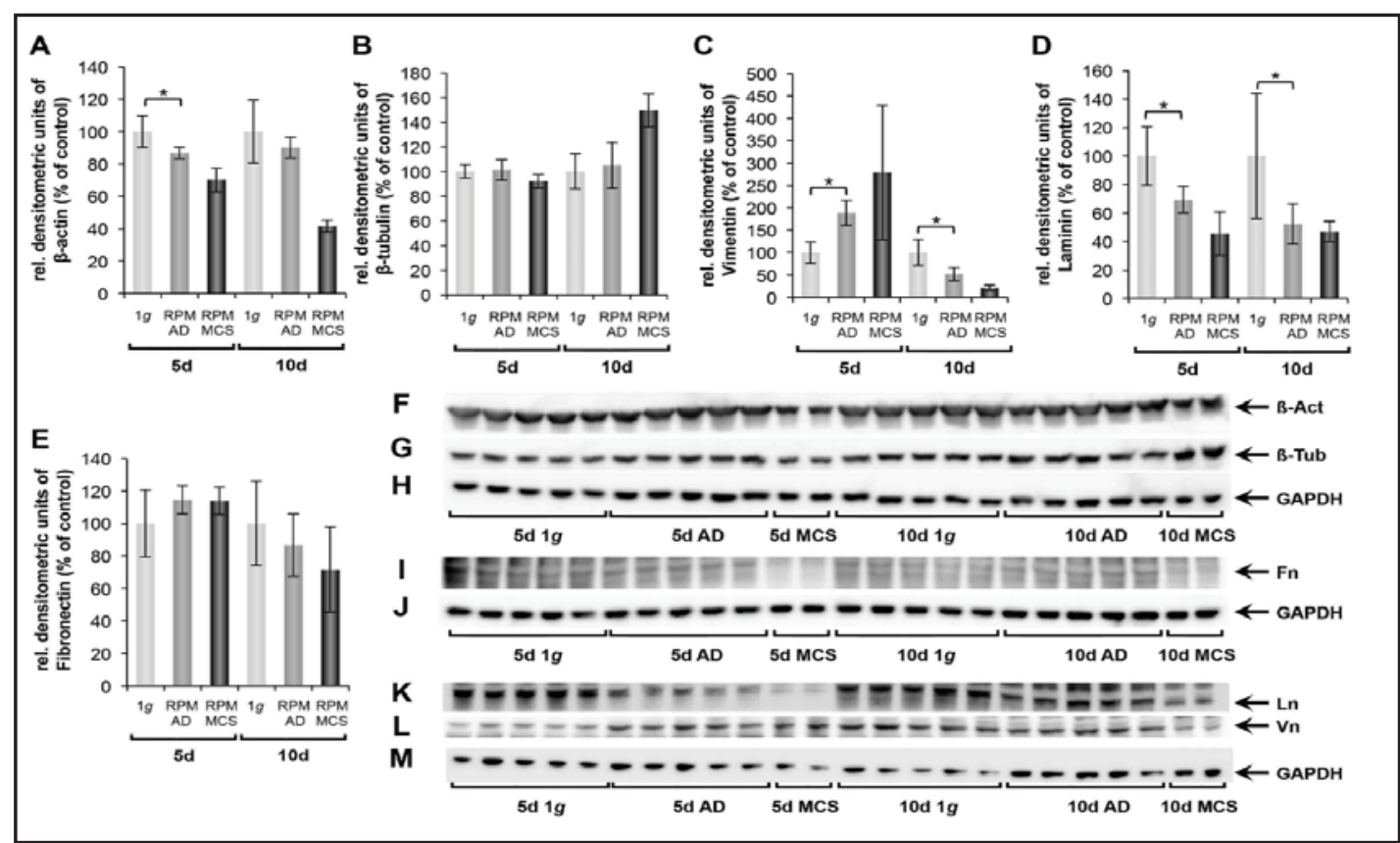

Fig. 4. Alterations of cytoskeletal and extracellular matrix protein content in ARPE-19 cells exposed to simulated microgravity. (A-E) Assessment of the relative protein content of (A) $\beta$-actin, (B) $\beta$-tubulin, (C) fibronectin, (D) laminin and (E) vimentin in $5 \mathrm{~d}$ - and $10 \mathrm{~d}$-samples correlated to GAPDH. The $5 \mathrm{~d}$ and $10 \mathrm{~d}$ $1 g$-controls were set to $100 \%$ (F-M) Protein content of 5 and $10 d$-experiments. $1 g$-control (1g), RPM-adherent (AD) and RPM-MCS (MCS) cells were analyzed by Western blotting for their protein content of (F) $\beta$-actin, (G) $\beta$-tubulin, (I) fibronectin, (K) laminin and (L) vimentin. As a loading control for the cell samples, an antibody against GAPDH was used (H, J and M). The images shown in F-H, I-J and K-M were obtained from three separate SDS-gels loaded with identical samples. Following SDS-PAGE and Western blotting membranes were incubated with different primary antibodies as indicated. $*=p<0.05$. The positions of $\beta$-actin ( $\beta$-Act), $\beta$-tubulin ( $\beta$-Tub), fibronectin (Fn), laminin ( $\mathrm{Ln})$, vimentin $(\mathrm{Vn})$, and GAPDH (GAPDH) are indicated on the right.

$1 g$-control level (Fig. 3M). In contrast to this finding the expression of ITGB3 in the $5 \mathrm{~d}-\mathrm{RPM}$ MCS-sample was almost unaltered compared to the $1 g$-control. However at $10 \mathrm{~d}$, the ITGB3 expression in both AD- and MCS-samples was significantly declined to approx. $37 \%$ and $45 \%$ of that of the control samples, respectively (Fig. 3M).

The content of cytoskeletal and ECM proteins is altered by RPM-induced microgravity

In the next step, we investigated whether these changes were also reflected in the amount of detectable proteins. Therefore we assessed the abundance of three cytoskeletal proteins ( $\beta$-actin, $\beta$-tubulin and vimentin) and two ECM proteins (laminin and fibronectin). GAPDH was used as loading control.

As shown in Fig. $4 \mathrm{~A}$ and $\mathrm{F}$ the amount of $\beta$-actin was significantly decreased in ADcells after $5 \mathrm{~d}$. A similar decline was observed in the AD-cells after 10d-exposure. Likewise, decreased levels of $\beta$-actin were seen in the MCS samples after both 5-and 10d-RPM-exposure. Even though the level of $\beta$-actin in these samples was reduced to $40-70 \%$ compared to the $1 g$-controls it was not significant. This was also the case for any of the other densitometric assessments of MCS, probably reflecting the modest numbers of MCS samples obtained from the RPM experiment.

The level of $\beta$-tubulin was static in 5d-RPM-AD- and 5d-RPM-MCS-samples as well as in the $10 \mathrm{~d}-\mathrm{RPM}$-AD-samples. In contrast, the amount of $\beta$-tubulin was increased in the 10d-RPM-MCS-samples (Fig. 4B and G). After 5d-RPM-exposure both AD and MCS cells exhibited increased levels of vimentin. However, after 10d both AD and MCS showed reduced levels of vimentin compared to $1 g$-controls (Fig. $4 \mathrm{C}$ and $\mathrm{L}$ ). The amount of laminin was 


\section{Cellular Physiology \\ Cell Physiol Biochem 2016;40:1-17 \\ \begin{tabular}{ll|l} 
DOI: 10.1159/000452520 & ( ) 2016 The Author(s). Published by S. Karger AG, Basel
\end{tabular}

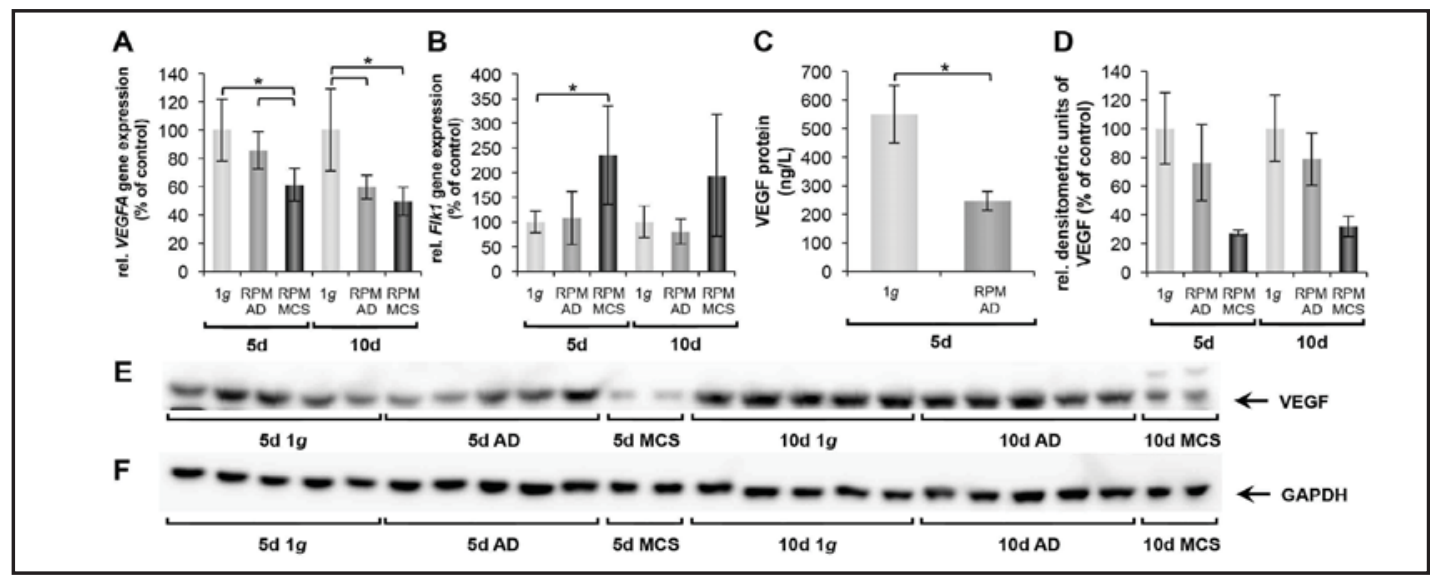

Fig. 5. Quantitative alterations of angiogenenic genes and protein content in ARPE-19 cells exposed to simulated microgravity. (A-B) Gene expression analyses of VEGFA and FLK1 (VEGFA receptor) examined by qRT-PCR. After $5 \mathrm{~d}$ and $10 \mathrm{~d} 1 \mathrm{~g}$-control, RPM-AD cells and RPM-MCS were analyzed for their relative expression levels of (A) VEGFA and (B) FLK1 correlated to $18 S$ rRNA. The $5 \mathrm{~d}$ and $10 \mathrm{~d} 1 \mathrm{~g}$-controls were set to $100 \%$ (C) Released VEGF protein in $1 g$ - and RPM-samples determined by a time resolved immunofluorometric assay (TRIFMA). (D) Assessment of the relative protein content of VEGF of samples from $5 \mathrm{~d}$ - and $10 \mathrm{~d}$-samples correlated to GAPDH. (E) Intracellular VEGF protein content of 5d- and 10d-experiments. $1 \mathrm{~g}$-control $(1 \mathrm{~g})$, RPM-adherent (AD) and RPM-MCS (MCS) cells were analyzed by Western blotting. (F) As a loading control for the cell samples, an antibody against GAPDH was used. $*=p<0.05$. The positions of VEGF and GAPDH are indicated on the right.

significantly decreased in AD-samples after 5d and 10d (Fig. 4D and K). Similarly, reduced amounts of laminin were observed in the MCS samples where as the level of fibronectin was static in all samples after a 5d- and 10d-RPM-exposure (Fig. 4E and I).

\section{Molecules of the VEGF pathway are changed by simulated microgravity}

In addition to the analysis of the cytoskeleton, gene expression, protein content, and release of factors playing a central role in angiogenesis were scrutinized. Expression of VEGF, an important driver of angiogenesis, was analyzed on the transcriptional as well as on the protein level for alterations during reduced gravity conditions.

The VEGF gene expression in $5 \mathrm{~d}$-samples revealed a significant down-regulation in RPM-AD- and RPM-MCS-ARPE-19 cells compared to the $1 g$-controls (Fig. 5A). After a 10d-exposure ARPE-19 cells exhibited a similar reduced VEGF expression in all groups (Fig. $5 \mathrm{~A})$.

Vascular endothelial growth factor receptor 2 (VEGFR2), also known as fetal liver kinase 1 (FLK1) or kinase insert domain receptor (KDR) is one of the VEGF-receptors. The expression of FLK1 in 5d-RPM-AD-samples revealed a mostly unchanged expression and a significant up-regulation in 5d-RPM-MCS-samples compared to the $1 g$-controls (Fig. 5B). After a 10d-exposure the ARPE-19 cells exhibited a similar FLK1 expression pattern in all groups compared to 5d (Fig. 5B).

Assessing the VEGF release into the medium after $5 \mathrm{~d}$ revealed a significantly lower content in RPM-samples of the ARPE-19 cells compared to the corresponding controls. As shown in Fig. 5C the content was more than 2-fold reduced from $550 \mathrm{ng} / \mathrm{L}$ in RPM-samples to $245 \mathrm{ng} / \mathrm{L}$ in the $1 g$-control cells.

Finally, we evaluated the intracellular content of VEGF protein by means of Western blotting analysis. The results presented in Fig. 5D-F show a decrease in the VEGF amount in $5 \mathrm{~d}$ - and $10 \mathrm{~d}$-samples exposed to simulated $\mu \mathrm{g}$ compared to the $1 \mathrm{~g}$-contol cells, thereby supporting the findings from the expression analysis as well as the investigation of released VEGF. Notably, the amount of VEGF was markedly reduced in the MCS-samples exposed to simulated microgravity (Fig. 5D). 


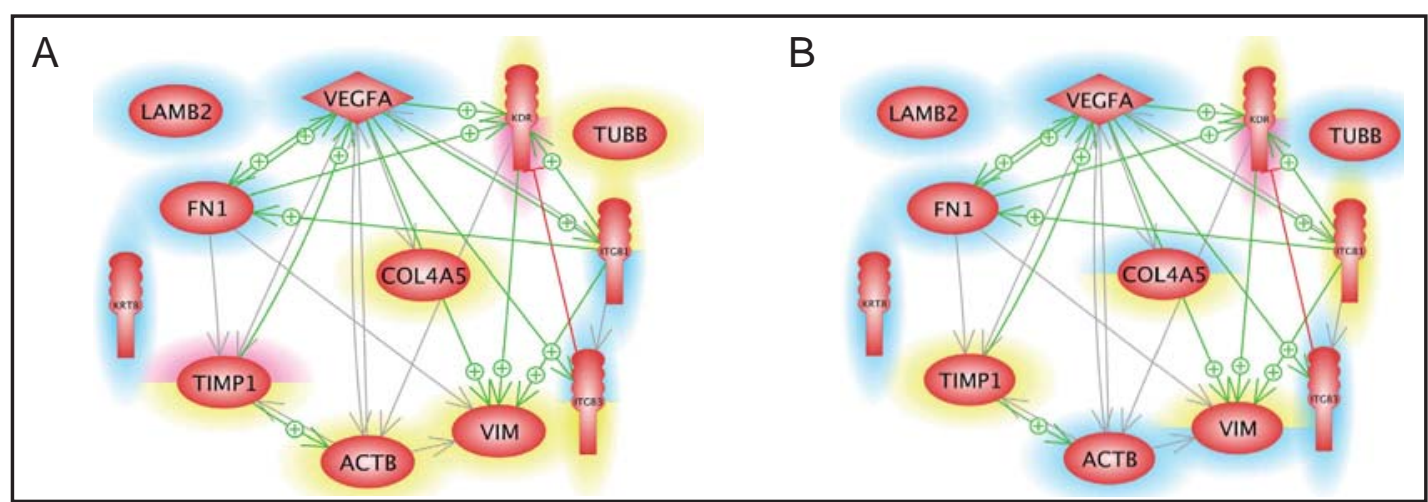

Fig. 6. Mutual interaction of selected genes at gene expression level. 12 selected genes, whose up- or down-regulation were analyzed by qRT-PCR after $5 \mathrm{~d}$ (A) and $10 \mathrm{~d}$ (B) of RPM-exposure and shown in Figs. 2, 3 and 5. Blue background indicates down-regulation and red background shows up-regulation. The yellow background refers to non-regulated genes. The lower part of each icon indicates the gene status in MCS cells, whereas the upper part indicates the status of the gene in the $\mathrm{AD}$ cells. The green arrows indicate activating and the red arrows inhibiting effects. The grey lines tell that interactions take place between the proteins, whose effects have not been clarified yet. The interaction network was built up using Elsevier Pathway Studio v.11.

Fig. 7. Mutual interaction and localization of proteins expressed in adherent cells after exposure to simulated microgravity. Interaction and localization of proteins coded by 12 selected genes found in AD cells after $5 d$ (upper part) and $10 \mathrm{~d}$ (lower part) on the RPM. The green arrows indicate activating and the red arrows inhibiting effects. The grey lines tell that interactions take place between the proteins, whose effects have not been clarified yet. Full lines indicate direct interaction, and dotted

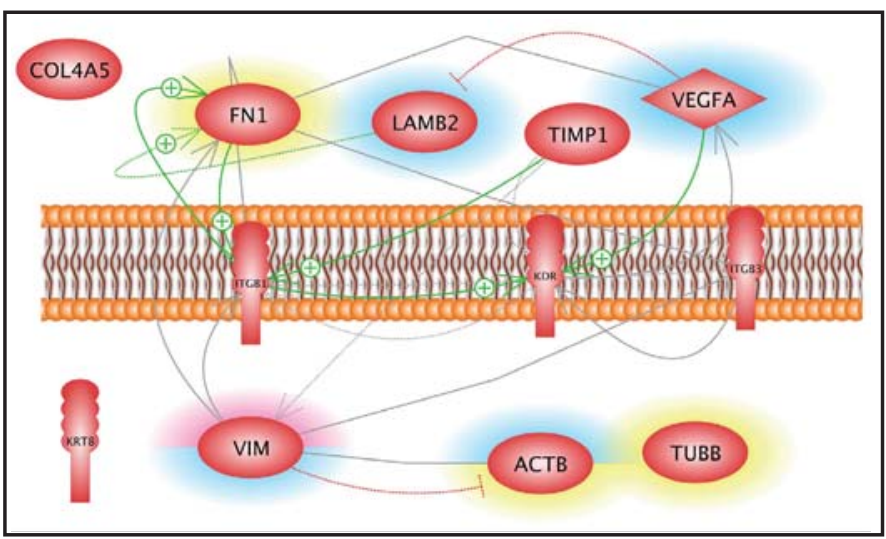
lines indicate regulation via intermediates. The icons on colored background indicate the proteins' increase (red) and decrease (blue) as compared to controls. The yellow background refers to unchanged protein content. The interaction network was built up using Elsevier Pathway Studio v.11.

Investigation of the underlying mechanisms of the phenotypically change of the cells

In order to uncover the underlying mechanisms for the observed 2D to 3D growth behavior transition in ARPE-19 cells, 12 genes, encoding proteins known to be involved in the maintenance and regulation of cell structure and shape or in cell adhesion, ECM, migration and angiogenesis, were selected (listed in Table 1). The Swissprot numbers of the proteins encoded by these genes were entered in the Elsevier Pathway Studio in order to gain knowledge about their interactions.

The pathway analysis shown in Fig. 6 provides an impression of the regulation of the 12 genes determined by qPCR analysis after $5 \mathrm{~d}$ (Fig. 6A) and 10d (Fig. 6B) of exposure to $\mu \mathrm{g}$ as depicted in Figs. 2, 3 and 5. It shows that apart from $\beta$-tubulin (TUBB), laminin (LAMB2) and keratin 8 (KRT8) the expression of the other 9 genes is mutually controlled within the frame of a network. These genes encode 9 individual products: 4 extracellular proteins, 3 membrane proteins and 2 cytoplasmic proteins (Fig. 7). The representation suggests that the $V E G F$ gene influences the majority of the neighboring genes and thus, may play a central role within this network of regulation. As determined by the PCR technique, the VEGF gene like the FN1 gene is down-regulated in MCS and AD cells after five days and remains down- 


\section{Cellular Physiology Cell Physiol Biochem 2016;40:1-17 \\ \begin{tabular}{ll|l} 
and Biochemistry Published online: November 14, 2016 & $\begin{array}{l}\text { ○ 2016 The Author(s). Published by S. Karger AG, Basel } \\
\text { www.karger.com/cpb }\end{array}$ \\
\hline
\end{tabular} \\ Corydon et al.: Impact of Simulated Microgravity on Human ARPE-19 Cells}

regulated until the tenth day of incubation. In parallel, the FLK1/KDR gene is up-regulated in MCS but unchanged in AD cells during the whole period of incubation. Also TIMP1, COL4A5 in MCS and VIM and ITGB1 in AD cells remain unchanged during the whole period of incubation.

Focusing on the proteins, the interaction analysis presented in Fig. 7 envisions a network, which stretches from extracellular space (upper part) via the membrane (drafted bilayer in the middle) to the cytoplasm (lower). It indicates that VEGFA together with ITGB1 is activating the KDR (FLK1), while TIMP1 supports enrichment of ITGB1, which together with LAMB2 has positive influence on fibronectin. The VIM content is enhanced after $5 \mathrm{~d}$ and affects the integrins $\beta-1$ and $\beta-3$ as well as $\beta$-actin and fibronectin.

\section{Discussion}

In the present study we investigated the influence of simulated microgravity on human RPE cells. For this purpose ARPE-19 cells were exposed to conditions of microgravity $(\mu g)$ using a RPM for $5 \mathrm{~d}$ and $10 \mathrm{~d}$, respectively. In addition, we also cultivated the cells under static conditions $(1 g)$.

Simulated microgravity (also termed functional weightlessness) is based on the assumption that a lack of weight load is perceived similarly to neutralization of sedimentation during weightlessness $(0 g)$ [28]. Even though the latter condition is never entirely reached under simulated circumstances, where weak residual acceleration forces are still active, ground based devices like RPM, RWV and fast-rotating clinostats have successfully reproduced microgravity responses [4]. However, these devices generally seem to underestimate the effects observed in real microgravity during spaceflights [29].

It is well known that a long-term spaceflight has immense impact on the health of humans in space and ocular changes are considered as a high human health risk of spaceflight [1-3]. Studies of astronauts participating in missions on the ISS have shown prominent adverse outcomes in visual function [1]. These spaceflight-induced vision changes include choroidal folds, optic disc edema, globe flattening and hyperopic shifts.

In the eye in vivo as well as under in vitro conditions RPE cells grow as a monolayer and 3D growth behavior of RPE cells is usually not observed. This feature is important for the RPE cells that constitutes the outer blood-retinal barrier and hence for the maintenance of the retinal homeostasis required for visual transduction. During simulated microgravity 3D assembly-structures, probably consisting of aggregated photoreceptor (PR) cells, can be observed when co-incubating HRet cells and ECs in the HRB [11]. It has been suggested that the microgravity-stimulated 3D assembly is promoted by cell-to-cell interaction together with secretion of growth factors like VEGF [11]. Likewise, multilayered RPE cells capable of proliferating and differentiating were observed following isolation [30, 31]. However, to our knowledge MCS derived from RPE cells exposed to microgravity has not yet been observed.

We used a RPM to explore whether simulated microgravity can stimulate ARPE-19 cells to form MCS, scrutinized changes in the F-actin cytoskeleton as well as the ECM, and investigated the expression of genes coding for proteins which are involved in cell structure, shape, migration, adhesion, or angiogenesis, and hence might play a role in the cellular capacity to sense gravitational alterations and development of MCS [21,32]. Interestingly we observed that a minor fraction of the ARPE-19 cells produced MCS after a 5d-RPM-exposure. We repeatedly detected that ARPE-19 cells developed into two phenotypically different populations; one subpopulation remaining adherent to the bottom of the cultivation flask, and another subpopulation that formed MCS freely floating in the cultivation medium (Fig. 1). The number and size of MCS increased after a 10d-RPM-exposure suggesting that reduced gravity conditions provided by the RPM promotes development of MCS and 3D growth.

Based on the nature of the presented study, it is not possible to conclude whether the observed MCS have pathologic effects in vivo. This would of cause require further analysis in vivo in rodents. The background for the relatively small number of MCS detected in the RPM-samples could be excessive cell confluence. For instance, no or very low numbers of 


\section{Cellular Physiology Cell Physiol Biochem 2016;40:1-17 \\ \begin{tabular}{l|l|l} 
and Biochemistry & Published online: November 14, 2016 & $\begin{array}{l}\text { () 2016 The Author(s). Published by S. Karger AG, Basel } \\
\text { www.karger.com/cpb }\end{array}$
\end{tabular}}

Corydon et al.: Impact of Simulated Microgravity on Human ARPE-19 Cells

MCS are observed in confluent FTC-133 cell cultures incubated on the RPM compared to semi-confluent samples [33, 34].

Tightly regulated expression of VEGF is mandatory for proper function of the eye and increased intra-ocular levels of this growth factor, may stimulate to neovascularization as observed in age-related macular degeneration (AMD) and proliferative diabetic retinopathy (DR) [35]. VEGF is part of a signaling pathway controlling important biological processes including proliferation, survival, migration, and actin reorganization [36]. The gene expression of VEGFA as well as synthesis and release of VEGF following incubation for $5 \mathrm{~d}$ and $10 \mathrm{~d}$ on the RPM was significantly decreased compared to the corresponding $1 g$-control samples. In particular, the decline in VEGFA and VEGF protein was more pronounced in the MCS-samples. This is in line with our recent findings using breast cancer cells (MCF-7) [21] and thyroid cancer cells (FTC-133) [37, 38] showing reduced VEGF levels. In addition, endothelial cells cultured on the RPM revealed an increased synthesis of VEGF [26, 39]. Similarly, retinal cells exposed to microgravity by using the HRB device displayed an upregulation of VEGF [11].

In response to the decreased VEGF levels observed in the present study the expression of VEGF receptor FLK1 at both time points increased significantly in RPM-MCS-samples, whereas a static expression was observed in the RPM-AD-samples. The elevated expression of FLK1 in MCS exposed to simulated microgravity is similar to the findings in MCS produced by MCF-7 cells cultivated on the RPM [21], suggesting that MCS originating from ARPE-19 and MCF-7 behave similarly in key regulatory aspects of angiogenesis.

Actin, tubulin, and cytokeratin are key components of the cytoskeleton and have various functions [40]. They play an important role in the perception of exterior signals including the gravity force [40]. In this study we found down-regulated $A C T B, T U B B$, and KRT8, and VIM in AD and MCS samples after 5d-RPM-exposure. This trend was further developed after a $10 \mathrm{~d}-\mathrm{RPM}$-experiment. After this time period, we observed a significant down-regulation in all samples with a clear tendency of MCSs displaying the lowest values (Fig. 2). In addition, $K R T 8$, which is a luminar epithelial marker [41], was significantly down-regulated in AD and MCS after $5 \mathrm{~d}$ and $10 \mathrm{~d}$ of cultivation on the RPM compared to the corresponding $1 \mathrm{~g}$-controls.

The presented densitometric analyses demonstrated a decreased amount of $\beta$-actin in $5 \mathrm{~d}$ - and $10 \mathrm{~d}-\mathrm{RPM}$ samples. Even though the decline was only significant in the $5 \mathrm{~d}-\mathrm{RPM}$ AD sample, the general trend of reduced protein levels in the RPM samples mirrored the observed reduction in ACTB expression. In contrast, the amount of $\beta$-tubulin seemed to be static with a tendency of increased levels in the $10 \mathrm{~d}$-RPM-MCS-samples, despite a significant reduction of TUBB expression in RPM-samples. The impact of simulated microgravity on the cytoskeleton of ARPE-19 cells seems to be different compared to e.g. FTC-133 human follicular thyroid cells and Nthy-ori 3-1 primary human thyroid follicular epithelial cells after a $7 \mathrm{~d}$ and 14d-exposure on the RPM in which the expression of ACTB and TUBB are up-regulated [23]. Similarly, increased levels of $\beta$-actin were observed in human MCF-7 breast cancer cells exposed to simulated microgravity for $5 \mathrm{~d}$ [21]. Using human chondrocytes Aleshcheva et al. showed that $A C T B$ and TUBB mRNAs were up-regulated after a $24 \mathrm{~h}$-incubation on the RPM [42]. However, no significant effect on the corresponding protein levels was observed [42]. The expression of VIM was unchanged compared to $1 \mathrm{~g}$-controls, whereas the protein level of vimentin was 3-fold increased [42]. In case of KRT8, this gene was down-regulated in ML-1 thyroid cancer cells, whereas it was found to be significantly up-regulated in follicular thyroid carcinoma cells (UCLA R082-W-1) [43].

As the conditions of the experiments regarding $A C T B$ and TUBB are similar, the observed differences in the cellular perception and handling of simulated microgravity most likely reflect the different origins of the investigated cells.

In addition to these findings, we observed that the F-actin filaments almost disappeared in favor of F-actin structures accumulating at the cell boundaries following RPM-exposure for $5 \mathrm{~d}$. However, F-actin staining pattern similar to the one observed in the $1 g$-control reappeared following after a $10 \mathrm{~d}$-exposure, advocating for a time-dependent adaptation to altered microgravity. Notably, no stress fibers were observed, probably due to the time point 


\section{Cellular Physiology Cell Physiol Biochem 2016;40:1-17 \\ \begin{tabular}{l|l|l}
\hline DOI: 10.1159/000452520 & (c) 2016 The Author(s). Published by S. Karger AG, Basel \\
\hline
\end{tabular} and Biochemistry Published online: November 14, 2016 www.karger.com/cpb}

Corydon et al.: Impact of Simulated Microgravity on Human ARPE-19 Cells

of analysis. This is in contrast to other studies showing stress fiber formation in e.g. FTC-133 and endothelial cells at shorter time points [24,39]. Another reason explaining why no stress fibers were observed might be the decrease in the expression levels of the integrins ITGB1 and ITGB3. Integrins are known to co-localize with moesin in microvilli in endothelial cells resulting in RhoA activation and hence induction of stress fiber production [44]. In addition, studies of e.g. mesenchymal stem cells exposed to simulated microgravity also revealed a decreased integrin signaling [45].

The ECM is composed of extracellular proteins secreted by the cells, thereby providing important structural, mechanical, and biochemical support to surrounding cells. We observed several alterations in components of the ECM. FN1 and LAMB2 were all found to be significantly down-regulated in all RPM-samples. We found COL4 to be similarly regulated after $5 \mathrm{~d}$ in RPM-samples as detected in $1 g$-samples, but significantly down-regulated after $10 \mathrm{~d}$ in AD-RPM-samples. A profound reduction was also observed in the MCS cell population harvested from the RPM, however it was not significant.

Simultaneously, the amount of laminin protein was decreased in AD and MCS cells after $5 \mathrm{~d}$ - and 10d-RPM-exposure as compared to the $1 \mathrm{~g}$-control cells, while equal amounts of fibronectin were found in all measurements. The observed reduction of the laminin protein content in cells thereby correlates to the observed decrease in LAMB2 expression. In case of fibronectin our data suggest that the amount of this protein is static during simulated microgravity even though the expression of FN1 is significantly decreased at both time points. These results are partly in line with the findings in MCF-7 breast cancer cells showing a down-regulation of FN1 as well as reduced levels of fibronectin in AD samples [21].

In concert with these findings, the CLSM analysis revealed an apparent reduction of fibronectin in cells exposed to simulated microgravity compared to $1 g$-controls. Even though CLSM is not a quantitative method, the obtained images shown in Fig. 3 indicated an overall reduction of anti-fibronectin-positive signals in samples experiencing simulated $\mu g$ compared to the $1 g$-controls (Fig. 3). The images resulting from the immunostaining and CLSM analysis also demonstrate that F-actin and fibronectin are localized at the cell boundaries and in the extracellular space around the MCS. This finding was also observed when endothelial cells were cultured on the RPM $[39,46]$. Fibronectin has been shown to play a key role in the 3D cell cohesion of FTC-133 thyroid cancer cells [47].

Components of the ECM play an important role in cell adhesion. In focal adhesion in which actin filaments are connected to the ECM or hemidesmosomes connecting intermediate filaments (such as cytokeratin) to the ECM. We detected a significant reduction of ITGB3 after $10 \mathrm{~d}$ in both cell populations harvested from the RPM. Similar, a decreased expression of ITGB1, however not significant, was observed in AD and MSC samples after $10 \mathrm{~d}$. Integrin- $\beta-1$ and $\beta-3$ are membrane proteins, involved in focal adhesion [44, 48]. Both integrins are described to be crucial for the activation of signaling pathways controlling important cellular processes including cytoskeleton rearrangements, angiogenesis, differentiation, and proliferation [44]. Similar to the situation of MCF-7 cells, the present findings indicate that integrin- $\beta-1$ is involved in the detachment of cells from the bottom of the culture flask. Moreover, COL4 was down-regulated. Therefore, we may suggest that simulated microgravity has a general impact on cell adhesion as both focal adhesion- and hemidesmosome-mediated processes are affected.

This impact is obviously not due to a one way event, but is exerted by a complex system of up- and down-regulation of gene expression (Fig. 6) as well as an increase or decrease of proteins (Fig. 7) [33]. Key players at protein and gene levels are VEGF and the ITGB1, which together act on the VEGF receptor. Although the VEGF content is lowered and the VEGF gene is down-regulated, the action of ITGB1 on the Flk1 receptor (also known as KDR or VEGFR-2) may keep the angiogenic signaling on an effective level [49].

The presented data suggest that simulated microgravity created by the RPM has a clear impact on the ARPE-19 cells. Taken together, we observed significant cytoskeletal alterations as well as a down-regulation of cytoskeletal genes following exposure to microgravity. Simultaneously, massive changes in the ECM were detected and a number of key ECM genes 


\section{Cellular Physiology Cell Physiol Biochem 2016;40:1-17 \begin{tabular}{ll|l} 
DOI: 10.1159/000452520 & $\begin{array}{l}\text { O 2016 The Author(s). Published by S. Karger AG, Basel } \\
\text { www.karger.com/cpb }\end{array}$ \\
\hline
\end{tabular} \\ Corydon et al.: Impact of Simulated Microgravity on Human ARPE-19 Cells}

were down-regulated. Finally, we observed a significant decrease in genes involved in cellular adhesion (ITGB1 and ITGB3) and tissue remodeling (TIMP1). These results suggest that weakening of cytoskeletal structures together with diminished capability to retain adhesion and stiffness of exterior structures in the RPE cells may contribute to the explanation of why reduced microgravity causes ocular changes as an outcome of compromised barrier to and abridged nursing of the PR layer. This notion may also explain why MCS are observed following exposure to reduced microgravity.

\section{Conclusion}

Our findings clearly show that simulated microgravity induces significant alterations in the F-actin-cytoskeleton and cytoskeleton-related proteins of ARPE-19, in addition to changes in cell growth behavior and gene expression patterns involved in cell structure, growth, shape, migration, adhesion and angiogenesis. Surprisingly, a minor fraction of the ARPE-19 cells produced MCS following incubation on the RPM suggesting that reduced gravity conditions promote 3D growth of ARPE-19 cells in vitro. With attention to these findings, we may suggest that weakening of interior and exterior cellular structures of the RPE cells following exposure to simulated microgravity may affect function of the retinal layer. However, further studies are required in order to investigate whether these changes contribute to the ocular changes observed in astronauts participating in prolonged spaceflights. A first step in this process might include analysis of RPE cells in real microgravity during parabolic flights as recently studied in primary human T lymphocytes [50] and thyroid cancer cells (FTC-133) [24].

\section{Acknowledgements}

This work was supported by the Gene Therapy Initiative Aarhus (GTI-Aarhus) funded by the Lundbeck Foundation (TJC, Grant No. R126-2012-12456), The Danish Eye Foundation (TJC), Aase og Ejnar Danielsen's Foundation (TJC), Knud and Edith Eriksen's Foundation (TJC), and the German Space Agency (DG, DLR; BMWi grant 50WB1524).

\section{Disclosure Statement}

The authors declare no competing financial interests.

\section{References}

1 Mader TH, Gibson CR, Pass AF, Kramer LA, Lee AG, Fogarty J, Tarver WJ, Dervay JP, Hamilton DR, Sargsyan A, Phillips JL, Tran D, Lipsky W, Choi J, Stern C, Kuyumjian R, Polk JD: Optic disc edema, globe flattening, choroidal folds, and hyperopic shifts observed in astronauts after long-duration space flight. Ophthalmology 2011;118:2058-2069.

2 Zwart SR, Gregory JF, Zeisel SH, Gibson CR, Mader TH, Kinchen JM, Ueland PM, Ploutz-Snyder R, Heer MA, Smith SM: Genotype, B-vitamin status, and androgens affect spaceflight-induced ophthalmic changes. FASEB J 2016;30:141-148.

3 Mader TH, Gibson CR, Lee AG: Choroidal folds in astronauts. Invest Ophthalmol Vis Sci 2016;57:592.

4 Grimm D, Wehland M, Pietsch J, Aleshcheva G, Wise P, van Loon J, Ulbrich C, Magnusson NE, Infanger M, Bauer J: Growing tissues in real and simulated microgravity: new methods for tissue engineering. Tissue Eng Part B 2014;20:555-566.

5 Borst AG, van Loon J: Technology and developments for the Random Positioning Machine, RPM. Microgravity Sci Tec 2009;21:287-292.

6 Herranz R, Anken R, Boonstra J, Braun M, Christianen PC, de Geest M, Hauslage J, Hilbig R, Hill RJ, Lebert M, Medina FJ, Vagt N, Ullrich O, van Loon JJ, Hemmersbach R: Ground-based facilities for simulation of microgravity: organism-specific recommendations for their use, and recommended terminology. Astrobiology 2013;13:1-17. 


\section{Cellular Physiology Cell Physiol Biochem 2016;40:1-17 \begin{tabular}{ll|l} 
DOI: 10.1159/000452520 & $\begin{array}{l}\text { ○ 2016 The Author(s). Published by S. Karger AG, Basel } \\
\text { www.karger.com/cpb }\end{array}$ \\
\hline
\end{tabular}}

Corydon et al.: Impact of Simulated Microgravity on Human ARPE-19 Cells

7 Becker JL, Prewett TL, Spaulding GF, Goodwin TJ: Three-dimensional growth and differentiation of ovarian tumor cell line in high aspect rotating-wall vessel: morphologic and embryologic considerations. J Cell Biochem 1993;51:283-289.

8 Freed LE, Vunjak-Novakovic G, Langer R: Cultivation of cell-polymer cartilage implants in bioreactors. J Cell Biochem 1993;51:257-264.

9 Schwarz RP, Goodwin TJ, Wolf DA: Cell culture for three-dimensional modeling in rotating-wall vessels: an application of simulated microgravity. J Tissue Cult Methods 1992;14:51-57.

10 Dutt K, Scott M, Wang M, Semple E, Sharma GP, Srinivasan A: Establishment of a human retinal cell line by transfection of SV40 T antigen gene with potential to undergo neuronal differentiation. DNA Cell Biol 1994;13:909-921.

11 Dutt K, Sanford G, Harris-Hooker S, Brako L, Kumar R, Sroufe A, Melhado C: Three-dimensional model of angiogenesis: coculture of human retinal cells with bovine aortic endothelial cells in the NASA bioreactor. Tissue Eng 2003;9:893-908.

12 Tombran-Tink J, Barnstable CJ: Space shuttle flight environment induces degeneration in the retina of rat neonates. Gravit Space Biol Bull 2005;18:97-98.

13 Hu DN, Savage HE, Roberts JE: Uveal melanocytes, ocular pigment epithelium, and Muller cells in culture: in vitro toxicology. Int J Toxicol 2002;21:465-472.

14 Roberts JE, Kukielczak BM, Chignell CF, Sik BH, Hu DN, Principato MA: Simulated microgravity induced damage in human retinal pigment epithelial cells. Mol Vis 2006;12:633-638.

15 Yao J, Tao ZF, Li CP, Li XM, Cao GF, Jiang Q, Yan B: Regulation of autophagy by high glucose in human retinal pigment epithelium. Cell Physiol Biochem 2014;33:107-116.

16 Li YJ, Jiang Q, Cao GF, Yao J, Yan B: Repertoires of autophagy in the pathogenesis of ocular diseases. Cell Physiol Biochem 2015;35:1663-1676.

17 Zha X, Wu G, Zhao X, Zhou L, Zhang H, Li J, Ma L, Zhang Y: PRDX6 Protects ARPE-19 Cells from Oxidative Damage via PI3K/AKT Signaling. Cell Physiol Biochem 2015;36:2217-2228.

18 Askou AL, Aagaard L, Kostic C, Arsenijevic Y, Hollensen AK, Bek T, Jensen TG, Mikkelsen JG, Corydon TJ: Multigenic lentiviral vectors for combined and tissue-specific expression of miRNA- and protein-based antiangiogenic factors. Mol Ther Methods Clin Dev 2015;2:14064.

19 Askou AL, Pournaras JA, Pihlmann M, Svalgaard JD, Arsenijevic Y, Kostic C, Bek T, Dagnaes-Hansen F, Mikkelsen JG, Jensen TG, Corydon TJ: Reduction of choroidal neovascularization in mice by adenoassociated virus-delivered anti-vascular endothelial growth factor short hairpin RNA. J Gene Med 2012;14:632-641.

20 Pihlmann M, Askou AL, Aagaard L, Bruun GH, Svalgaard JD, Holm-Nielsen MH, Dagnaes-Hansen F, Bek T, Mikkelsen JG, Jensen TG, Corydon TJ: Adeno-associated virus-delivered polycistronic microRNA-clusters for knockdown of vascular endothelial growth factor in vivo. J Gene Med 2012;14:328-338.

21 Kopp S, Slumstrup L, Corydon TJ, Sahana J, Aleshcheva G, Islam T, Magnusson NE, Wehland M, Bauer J, Infanger M, Grimm D: Identifications of novel mechanisms in breast cancer cells involving ductlike multicellular spheroid formation after exposure to the Random Positioning Machine. Sci Rep 2016;6:26887.

22 Dollerup P, Thomsen TM, Nejsum LN, Faerch M, Osterbrand M, Gregersen N, Rittig S, Christensen JH, Corydon TJ: Partial nephrogenic diabetes insipidus caused by a novel AQP2 variation impairing trafficking of the aquaporin-2 water channel. BMC Nephrol 2015;16:217.

23 Kopp S, Warnke E, Wehland M, Aleshcheva G, Magnusson NE, Hemmersbach R, Corydon TJ, Bauer J, Infanger M, Grimm D: Mechanisms of three-dimensional growth of thyroid cells during long-term simulated microgravity. Sci Rep 2015;5:16691.

24 Corydon TJ, Kopp S, Wehland M, Braun M, Schutte A, Mayer T, Hulsing T, Oltmann H, Schmitz B, Hemmersbach R, Grimm D: Alterations of the cytoskeleton in human cells in space proved by life-cell imaging. Sci Rep 2016;6:20043.

25 Aleshcheva G, Wehland M, Sahana J, Bauer J, Corydon TJ, Hemmersbach R, Frett T, Egli M, Infanger M, Grosse J, Grimm D: Moderate alterations of the cytoskeleton in human chondrocytes after short-term microgravity produced by parabolic flight maneuvers could be prevented by up-regulation of BMP-2 and SOX-9. FASEB J 2015;29:2303-2314.

26 Grimm D, Bauer J, Ulbrich C, Westphal K, Wehland M, Infanger M, Aleshcheva G, Pietsch J, Ghardi M, Beck M, El-Saghire H, de Saint-Georges L, Baatout S: Different responsiveness of endothelial cells to vascular endothelial growth factor and basic fibroblast growth factor added to culture media under gravity and simulated microgravity. Tissue Eng Part A 2010;16:1559-1573.

27 Grosse J, Warnke E, Pohl F, Magnusson NE, Wehland M, Infanger M, Eilles C, Grimm D: Impact of sunitinib on human thyroid cancer cells. Cell Physiol Biochem 2013;32:154-170. 


\section{Cellular Physiology Cell Physiol Biochem 2016;40:1-17 \begin{tabular}{ll|l} 
DOI: 10.1159/000452520 & $\begin{array}{l}\text { ○ 2016 The Author(s). Published by S. Karger AG, Basel } \\
\text { www.karger.com/cpb }\end{array}$ \\
\hline
\end{tabular}}

Corydon et al.: Impact of Simulated Microgravity on Human ARPE-19 Cells

28 Hejnowicz Z, Sondag C, Alt W, Sievers A: Temporal course of graviperception in intermittently stimulated cress roots. Plant Cell Environ 1998;21:1293-1300.

29 Wuest SL, Richard S, Kopp S, Grimm D, Egli M: Simulated microgravity: critical review on the use of random positioning machines for mammalian cell culture. Biomed Res Int 2015;2015:971474.

30 Framme C, Kobuch K, Eckert E, Monzer J, Roider J: RPE in perfusion tissue culture and its response to laser application. Preliminary report. Ophthalmologica 2002;216:320-328.

31 Liang L, Yan RT, Ma W, Zhang H, Wang SZ: Exploring RPE as a source of photoreceptors: differentiation and integration of transdifferentiating cells grafted into embryonic chick eyes. Invest Ophthalmol Vis Sci 2006;47:5066-5074.

32 Ma X, Wehland M, Schulz H, Saar K, Hubner N, Infanger M, Bauer J, Grimm D: Genomic approach to identify factors that drive the formation of three-dimensional structures by EA.hy 926 endothelial cells. PLoS One 2013;8:e64402.

33 Riwaldt S, Bauer J, Pietsch J, Braun M, Segerer J, Schwarzwalder A, Corydon TJ, Infanger M, Grimm D: The importance of caveolin-1 as key-regulator of three-dimensional growth in thyroid cancer cells cultured under real and simulated microgravity conditions. Int J Mol Sci 2015;16:28296-28310.

34 Riwaldt S, Pietsch J, Sickmann A, Bauer J, Braun M, Segerer J, Schwarzwalder A, Aleshcheva G, Corydon TJ, Infanger M, Grimm D: Identification of proteins involved in inhibition of spheroid formation under microgravity. Proteomics 2015;15:2945-2952.

35 Corydon TJ: Antiangiogenic eye gene therapy. Hum Gene Ther 2015;26:525-537.

36 Ferrara N, Gerber HP, LeCouter J: The biology of VEGF and its receptors. Nat Med 2003;9:669-676.

37 Grosse J, Wehland M, Pietsch J, Schulz H, Saar K, Hubner N, Eilles C, Bauer J, Abou-El-Ardat K, Baatout S, Ma $\mathrm{X}$, Infanger M, Hemmersbach R, Grimm D: Gravity-sensitive signaling drives 3-dimensional formation of multicellular thyroid cancer spheroids. FASEB J 2012;26:5124-5140.

38 Warnke E, Pietsch J, Wehland M, Bauer J, Infanger M, Gorog M, Hemmersbach R, Braun M, Ma X, Sahana J, Grimm D: Spheroid formation of human thyroid cancer cells under simulated microgravity: a possible role of CTGF and CAV1. Cell Commun Signal 2014;12:32.

39 Infanger M, Ulbrich C, Baatout S, Wehland M, Kreutz R, Bauer J, Grosse J, Vadrucci S, Cogoli A, Derradji H, Neefs M, Kusters S, Spain M, Paul M, Grimm D: Modeled gravitational unloading induced downregulation of endothelin-1 in human endothelial cells. J Cell Biochem 2007;101:1439-1455.

40 Vorselen D, Roos WH, MacKintosh FC, Wuite GJ, van Loon JJ: The role of the cytoskeleton in sensing changes in gravity by nonspecialized cells. FASEB J 2014;28:536-547.

41 Vantangoli MM, Madnick SJ, Huse SM, Weston P, Boekelheide K: MCF-7 human breast cancer cells form differentiated microtissues in scaffold-free Hydrogels. PLoS One 2015;10:e0135426.

42 Aleshcheva G, Sahana J, Ma X, Hauslage J, Hemmersbach R, Egli M, Infanger M, Bauer J, Grimm D: Changes in morphology, gene expression and protein content in chondrocytes cultured on a random positioning machine. PLoS One 2013;8:e79057.

43 Riwaldt S, Bauer J, Wehland M, Slumstrup L, Kopp S, Warnke E, Dittrich A, Magnusson NE, Pietsch J, Corydon TJ, Infanger M, Grimm D: Pathways regulating spheroid formation of human follicular thyroid cancer cells under simulated microgravity conditions: A genetic approach. Int J Mol Sci 2016;17:528.

44 Hynes RO: Integrins: bidirectional, allosteric signaling machines. Cell 2002;110:673-687.

45 Meyers VE, Zayzafoon M, Gonda SR, Gathings WE, McDonald JM: Modeled microgravity disrupts collagen I/integrin signaling during osteoblastic differentiation of human mesenchymal stem cells. J Cell Biochem 2004;93:697-707.

46 Infanger M, Kossmehl P, Shakibaei M, Baatout S, Witzing A, Grosse J, Bauer J, Cogoli A, Faramarzi S, Derradji H, Neefs M, Paul M, Grimm D: Induction of three-dimensional assembly and increase in apoptosis of human endothelial cells by simulated microgravity: impact of vascular endothelial growth factor. Apoptosis 2006;11:749-764.

47 Pietsch J, Sickmann A, Weber G, Bauer J, Egli M, Wildgruber R, Infanger M, Grimm D: A proteomic approach to analysing spheroid formation of two human thyroid cell lines cultured on a random positioning machine. Proteomics 2011;11:2095-2104.

48 Yeh YC, Lin HH, Tang MJ: A tale of two collagen receptors, integrin beta1 and discoidin domain receptor 1, in epithelial cell differentiation. Am J Physiol Cell Physiol 2012;303:C1207-1217.

49 Santambrogio M, Valdembri D, Serini G: Increasing traffic on vascular routes. Mol Aspects Med 2011;32:112-122.

50 Tauber S, Hauschild S, Paulsen K, Gutewort A, Raig C, Hurlimann E, Biskup J, Philpot C, Lier H, Engelmann F, Pantaleo A, Cogoli A, Pippia P, Layer LE, Thiel CS, Ullrich O: Signal transduction in primary human T lymphocytes in altered gravity during parabolic flight and clinostat experiments. Cell Physiol Biochem 2015;35:1034-1051. 